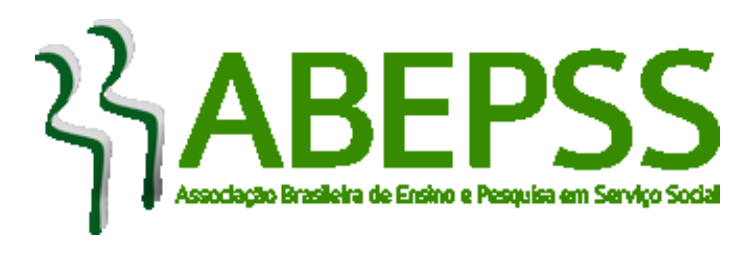

\title{
SUBSÍDIOS PARA O DEBATE SOBRE A QUESTÃO ÉTNICO-RACIAL NA FORMAÇÃO EM SERVIÇO SOCIAL ${ }^{1}$
}

\section{INTRODUÇÃO}

O documento que a Associação Brasileira de Ensino e Pesquisa em Serviço Social (ABEPSS) traz ao público, em especial, ao conjunto de seus associados, cumpre o objetivo de contribuir e direcionar o debate sobre a questão étnico-racial na formação e no trabalho profissional das/os assistentes sociais.

Ao longo das últimas décadas, o Serviço Social brasileiro vem construindo um projeto de profissão sustentado por um arcabouço teórico metodológico direcionado pelo esforço de apreensão da realidade sob a orientação do marxismo e uma direção ético-política vinculada às lutas da classe trabalhadora. Essa construção, embora recente, nos deixa um importante legado de amadurecimento teórico-político e coloca o importante desafio, sobretudo às entidades dessa profissão, de construir táticas e estratégias de consolidação do projeto profissional crítico.

Diversos desafios foram e continuam postos ao Serviço Social ao longo de sua história. 0 debate sobre a questão étnico-racial e sua inserção nos currículos é um deles. A proposta deste subsídio é justamente assumir a tarefa coletiva de construir o avanço do debate entre a categoria.

Almeida (2013) menciona que desde os anos 80 as assistentes sociais engajadas nas lutas antirracistas vêm tocando a pauta dentro e fora da profissão, seja na articulação com o movimento negro, seja nos encontros da categoria. Somado a isso, temos a aprovação do Código de Ética de 1993 que demarca em seus princípios um exercício profissional que combata toda forma de opressão e discriminação. Além disso, as Diretrizes Curriculares da ABEPSS de 1996 apontam em seu conteúdo programático a incorporação de conteúdos obrigatórios nos currículos acadêmicos sobre a questão étnico-racial.

Em 2010, a criação do Grupo Temático de Pesquisa (GTP) "Serviço Social, Relações de Exploração/Opressão de Gênero, Raça/Etnia e Sexualidades”, ampliou significativamente a sistematização das produções acadêmicas da área, assim como o apontamento de novas pesquisas e de tendências do debate, o incentivo a novas produções, e a articulação entre os grupos de pesquisa sobre o debate étnico-racial. Este trabalho é orientado pela ementa construída pelo próprio GTP, atualizada em 2016, qual seja:

Raça/ Etnia: Estado e raça. Formação social e Divisão racial do trabalho no capitalismo. Raça e etnia como construção social. Pensamento Social e raça/ etnia.

\footnotetext{
${ }^{1}$ Equipe de elaboração do documento base: João Paulo da Silva Valdo (ABEPSS/UFF) Maria Helena Elpidio (ABEPSS/UFES)

Roseli Rocha (FIOCRUZ)
}

DOI 10.22422/temporalis.2018v18n36p422-434 
Desigualdades étnico-raciais, de gênero, geração e classe. Indicadores sociodemográficos e desigualdade racial. Movimentos sociais e antirracismo. Serviço Social e Políticas públicas de promoção da igualdade racial. Formação profissional e desigualdades étnico-raciais: avanços e desafios para o projeto ético-político do serviço social. Exercício profissional, preconceito e discriminação racial (ASSOCIAÇÃO BRASILEIRA DE ENSINO E PESQUISA EM SERVIÇO SOCIAL, 2016).

No entanto, ainda temos uma tímida produção e ações políticas - embora estejam numa crescente - no campo da luta antirracista no Serviço Social, que reverbera na formação profissional limitando o aprofundamento de uma analise da totalidade da realidade brasileira, ou seja, em que medida o racismo impacta o processo de formação e trabalho profissional.

Buscando superar a lacuna em torno da discussão étnico-racial é que pautamos a necessidade do estudo dessa temática no processo de formação e suas implicações ao exercício profissional (ROCHA, 2009). Por isso, coadunamos com as questões apontadas por Rocha (2009) ao perguntar: a ausência do debate étnico-racial nos currículos acadêmicos comprometem a formação e o exercício profissional que combata práticas discriminatórias e preconceituosas? O desconhecimento das expressões da ideologia do racismo reforçam práticas racistas? Quais as dificuldades das assistentes sociais diante do racismo institucional e as violações de direitos decorrente do racismo?

Esses questionamentos exigem competência teórico-política acerca dos fundamentos da questão étnico-racial na realidade brasileira, assim como de suas diversas expressões na produção e reprodução da vida social. Requerem, ainda, conhecimento das contribuições da articulação deste debate, parte constitutiva da vida social e da realidade brasileira aos fundamentos do Serviço Social.

A construção de alternativas de enfrentamento ao racismo ocorre nas transformações das relações étnico-raciais e por isso ultrapassa a tarefa de uma profissão ou da consciência do individuo. Contudo, o Serviço Social, diante de todo acúmulo histórico e seu compromisso com as lutas sociais, tem todas as condições de contribuir no fortalecimento do debate e na construção de ações de combate ao racismo (EURICO, 2017).

[...] mais do que 'fotografar' a realidade da incorporação da temática étnico-racial pelo Serviço Social, o importante nesse processo é contribuir para que a discussão étnico-racial, com toda a sua riqueza e sua dimensão histórica, saia dos porões acadêmicos e assuma espaço de visibilidade e importância político-acadêmica nas pesquisas de pós-graduação, nas atividades de extensão universitária e, sobretudo, no processo de formação profissional (ROCHA, 2014, p.181).

Com o objetivo de construir coletivamente para o aprofundamento do debate étnico-racial com as Unidades de Formação Acadêmicas (UFA) e demais espaços formativos na graduação, pós-graduação e na perspectiva da educação permanente, o material ora apresentado oferecerá aos profissionais, docentes e discentes, elementos iniciais para a implementação de ações concretas no âmbito do ensino, pesquisa e extensão.

Após o documento ser apresentado no ENPESS 2018, nossa proposta é que cada regional incentive atividades nas UFAs e organize dois ciclos de debates regionais no primeiro 


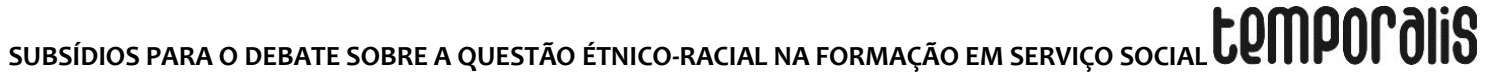

semestre de 2019, com o intuito de aprofundar a discussão com a base profissional e incorporar elementos teóricos, empíricos e políticos ao documento, contribuindo para a versão final. As sistematizações elaboradas pelas regionais serão enviadas ao Grupo de Trabalho (GT) Subsídio ao Debate da Questão Étnico-Racial na Formação em Serviço Social da ABEPSS, que terá a tarefa de finalizar uma versão final do documento e apresentar na Oficina Nacional da ABEPSS de 2019.

Nesses termos, ao elaborar este documento base para o Subsídio ao Debate da Questão Étnico-Racial na Formação em Serviço Social, a gestão da ABEPSS (2017-2018) coloca como uma das centralidades da sua agenda política o compromisso na construção de um projeto de formação profissional antirracista e reconhece o significado sócio-histórico do debate étnico-racial para o Serviço Social brasileiro.

\section{OBJETIVOS}

\subsection{Objetivo geral}

Oferecer subsídios para a inclusão e o fortalecimento do debate da questão étnico-racial contribuindo para uma formação em Serviço Social antirracista a partir do desenvolvimento de atividades de ensino, pesquisa e extensão (graduada e pós-graduada);

\subsection{Objetivos específicos}

- Evidenciar a necessidade sócio-histórica do debate acerca da questão étnico-racial na formação em Serviço Social, na perspectiva de totalidade;

- Subsidiar conteúdos programáticos aos currículos de Serviço Social para implementação de disciplinas obrigatórias, optativas, laboratórios e oficinas na graduação e linhas de pesquisa e disciplinas na pós-graduação;

- Direcionar e fomentar atividades de educação permanente aos profissionais, docentes e discentes, articulando trabalho e formação;

- Estimular a criação de grupos de pesquisa e de produção de conhecimento na formação graduada e pós-graduada.

\section{JUSTIFICATIVA}

\subsection{Premissas fundamentais para apreensão do debate}

O debate sobre o conceito de raça/etnia é fundamental para a compreensão da questão social na dialética da formação social brasileira. A premissa inicial proposta nesse documento é contribuir na construção desse conceito para o entendimento da relação entre raça/etnia e classe como estrutural e estruturante das relações sociais, considerando que o racismo é uma das fundamentes dessas relações no Brasil.

No ano de 1911, o então diretor do Museu Nacional, João Batista de Lacerda, representando o Brasil no Congresso Mundial sobre Raça, em Londres, defendia a ideia de que a miscigenação brasileira, ao contrário do que se acreditava acerca do perigo da mistura das raças para a formação de um povo híbrido, degenerado física e intelectualmente, seria, na verdade, a possibilidade real e concreta de embranquecer a população mestiça. Afirmou 
aos participantes do referido congresso, que, no prazo máximo de cem anos, os negros não existiriam mais no país, pois através da miscigenação, o gene branco que se acreditava ser mais forte e predominante que o gene negro, embranqueceria a nação.

Nesse período histórico, vivíamos sob a hegemonia do pensamento europeu determinista e o racismo científico exercia forte influência sobre as produções dos intelectuais brasileiros. A miscigenação, na perspectiva da teoria do embranquecimento, surge então como uma porta de saída interessante e viável para a constituição de uma nação branca, livre da mancha negra, tão indesejada pela classe dominante no período pós-abolição.

Entretanto, ao contrário do que havia sido previsto pelo então diretor do Museu Nacional, os últimos dados do IBGE revelam que, após os cem anos do congresso em Londres, a população brasileira é hoje constituída majoritariamente por negros, ou seja, pretos e pardos. Estes representam hoje 54\% do conjunto da população.

Todavia, embora a tese da superioridade genética branca sobre as demais raças tenha sido superada pela própria ciência, que afirma existir apenas uma única raça - a humana -, a ideia acerca daquela pseudo superioridade do branco ainda persiste. Se não em relação aos aspectos biológicos, há em relação à cultura, à sociabilidade e a fatores econômicos e políticos.

Para Guimarães (2006), a “[...] raça não é apenas uma categoria política necessária para organizar a resistência ao racismo no Brasil”. Ela é também categoria analítica indispensável, pois, é “[...] a única que revela que as discriminações e desigualdades que a noção brasileira de 'cor' enseja são efetivamente raciais e não apenas de 'classe"” (GUIMARÃES, 2006).

Numa perspectiva mais crítica, no que diz respeito às relações sociais sustentadas sobre a estrutura de exploração e dominação de classe, Hasenbalg (1979) ressalta que a raça é um dos critérios mais importantes no processo de recrutamento para acesso a posições na estrutura de classes. Nos chama a atenção para o fato de que, embora o racismo se expresse de diferentes formas, no tempo e no espaço, ele "[...] caracteriza todas as sociedades capitalistas multi-raciais contemporâneas" (HASENBALG, 1979). Afirma, ainda, que "o racismo é mais do que um reflexo epifenomêncio da estrutura econômica [...]. Sua persistência histórica não deveria ser explicada como um mero legado do passado, mas como servindo aos [...] interesses do grupo racialmente supraordenado no presente" (HASENBALG, 1979).

E nessa mesma perspectiva, lanni (2004) afirma que raça não é uma condição biológica [...], e sim uma condição social [...] criada, reiterada e desenvolvida na trama das relações sociais, envolvendo jogos de forças sociais e processos de dominação e apropriação. Seyferth (2002) parece ter a mesma compreensão acerca da ideia de raça. Para ela, raça foi uma invenção desenvolvida para interpretar a história das nações e, a partir do século XX, "[...] foi transformada num conceito biológico contaminado por questões políticas, jogando com a ideia do antagonismo inato entre raças diferentes" (SEYFERTH, 2002).

O conceito de raça expressa sentidos distintos ao longo da história, bem como diferentes definições e origens. É um conceito complexo e multifacetado, mas necessário para a 


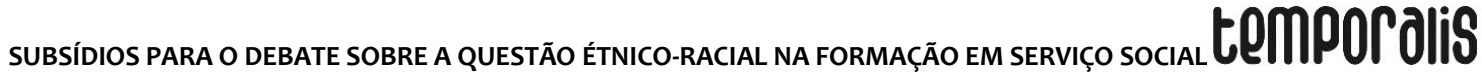

análise das relações raciais, tanto no âmbito acadêmico, como no âmbito das políticas públicas.

Ainda que raça não tenha nenhum sentido biológico, sob o ponto de vista sócio-histórico, raça continua sendo um recurso político-ideológico de estigmatização, segregação, dominação e exploração em todo o mundo. Embora sua existência não seja mais validada pelas ciências naturais, sua existência é real nas mentes e na vida social concreta dos sujeitos. E mesmo esvaziada de sentido biológico, a ideia de raça persiste, sobretudo, no âmbito das relações de poder e dominação para a manutenção de uma sociedade desigual.

A constatação científica da inexistência de raças humanas que, a priori, devia ser algo positivo e importante para o combate a qualquer tipo de discriminação e preconceito fundamentados na ideia de raça, não alterou o modelo pelo qual a sociedade de classes utiliza a condição racial como importante mecanismo de manutenção de privilégios de uns em detrimento dos direitos de outros.

Para os movimentos negro e antirracista, a afirmação da categoria raça é imprescindível para a análise dessas relações no Brasil. A sua supressão incorre no risco do daltonismo universalista, como nos alerta Nascimento e Nascimento (2004). O seu abandono pode nos impedir de enxergar o racismo como um elemento estrutural e estruturante das relações sociais numa sociedade de classes.

Por isso a utilização de raça como uma categoria social é indispensável para a análise e compreensão das relações sociais de dominação e desigualdade racial, tão fortemente presentes em diversas sociedades, mas, sobretudo, nas que se estruturam sobre os pilares de exploração capitalista.

Outro aspecto importante a ser aqui destacado é o conceito de etnia que, por vezes, é utilizado como sinônimo de raça. Entendemos que embora possa ser assim compreendida, e que em muitos estudos e pesquisas aparecem com esse sentido, acreditamos que são categorias distintas e significados também diferentes. Cashomore (2000) conceitua etnia no Dicionário de Relações Étnicas e Raciais.

\footnotetext{
Em sua forma contemporânea, 'étnico' ainda mantém o seu significado básico, no sentido em que descreve um grupo possuidor de algum grau de coerência e solidariedade, composto por pessoas conscientes, ao menos em forma latente, de terem origens e interesses comuns. Um grupo étnico não é mero agrupamento de pessoas ou de um setor da população, mas uma agregação consciente de pessoas unidas ou proximamente relacionadas por experiências compartilhadas (CASHOMORE, 2000, p. 196).
}

Para Munanga (2003) etnia é um conjunto de indivíduos que têm em comum a ancestralidade, a língua, a religião ou cosmovisão, a cultura, morando geograficamente num mesmo território (MUNANGA, 2003).

A apropriação das categorias raça e etnia para as análises e reflexões nas ciências sociais é fundamental, sobretudo, no Serviço Social, que atua no âmbito das expressões da questão social, que, por sua vez, atingem prioritariamente, na realidade brasileira, as populações negras e indígenas. 
Nesse sentido, sob a perspectiva da totalidade social, o debate acerca das opressões e exploração de classe não deve ocorrer descolado das determinações étnico-raciais, que são estruturais e estruturantes das relações sociais em todas as esferas da vida social. Compreensão que é fundamental para a articulação com o debate da formação em Serviço Social.

\subsection{Considerações sobre a apreensão da questão étnico-racial no Serviço Social}

Podemos dizer que o racismo é uma forma sistemática de discriminação que tem a raça como fundamento, e que se manifesta por meio de práticas conscientes ou inconscientes que culminam em desvantagens ou privilégios para indivíduos, a depender do grupo racial ao qual pertençam (ALMEIDA, 2018, p. 25).

O Serviço Social brasileiro, ao longo das últimas décadas, vêm se constituindo como uma profissão inscrita na sociedade brasileira compreendendo a atuação profissional socialmente determinada no campo do trabalho e do assalariamento, com suas contradições e desdobramentos históricos. Sabemos que as transformações societárias em curso incidem diretamente sobre as condições de vida e manutenção da classe trabalhadora. Sendo assim, profissionais e usuários sofrem cotidianamente os impactos do agravamento da questão social e da ofensiva do Estado neoliberal que, juntos, aceleram o crescimento de reações conservadoras e repressivas para o conjunto da classe. Partindo desta realidade, ampliam-se as tensões e os desafios para a profissão, exigindo maior esforço para articular no seu exercício as dimensões teórico-metodológica, ético-política e técnico-operativa para decifrar as artimanhas do tempo presente.

O necessário debate da questão étnico-racial efetiva-se na medida em que a mesma, sob o rigor da análise crítica da sociedade capitalista e seu processo de produção e reprodução, deve ser considerada como um dos eixos estruturais e estruturantes das relações sociais. Sobretudo, quando se tem por horizonte a superação desta sociabilidade, que alcança no atual estágio de crise do capital os patamares mais insustentáveis de vida, gerando a absurda contradição entre o modo de produção e o pleno desenvolvimento das condições de vida e usufruto coletivo do que é produzido por parte de seus/suas reais produtores/as. Na relação entre racismo e capitalismo, Almeida (2018) afirma:

O racismo, de acordo com esta posição é uma manifestação das estruturas do
capitalismo, que foram forjadas pela escravidão. Isso significa dizer que a
desigualdade racial é um elemento constitutivo das relações mercantis e das
relações de classe, de tal sorte que a modernização da economia e até seu
desenvolvimento também podem representar momentos de adaptação dos
parâmetros raciais a novas etapas da acumulação capitalista. Em suma: para se
renovar, o capitalismo precisa, muitas vezes, renovar o racismo, como, por
exemplo, substituir o racismo oficial e a segregação legalizada pela indiferença
em face da igualdade racial sob o manto da democracia (ALMEIDA, 2008, p. 144).

Imersa no irracionalismo da miséria da razão (COUTINHO, 2010) a conjuntura impõe o exame crítico do real como estratégia fundamental para conhecer a "rica trama das relações sociais" e de seus sujeitos, uma vez que 
sussions sara o o

O conhecimento criterioso dos processos sociais e de sua vivência pelos indivíduos sociais poderá alimentar ações inovadoras, capazes de propiciar o atendimento às efetivas necessidades sociais dos segmentos subalternizados, alvos das ações institucionais. Esse conhecimento é pré-requisito para impulsionar a consciência crítica e uma cultura política democrática para além das mistificações difundidas pela prática social em geral e particularmente pela mídia (IAMAMOTO, 2007, p. 200).

Desta forma, o debate étnico-racial possui de forma inequívoca uma profunda relação com a dimensão essencial do trabalho e da questão social. Ele se apresenta como mediação fundamental do objeto da profissão, qual seja, as diferentes expressões da questão social e a efetiva promoção de ações concretas para a sua superação, enfrentamento com base em uma educação e formação profissional antirracista, uma vez que

A questão social expressa, portanto, desigualdades econômicas, políticas sociais públicas e culturais das classes sociais, mediatizadas por disparidades nas relações de gênero, características étnico-raciais e formações regionais, colocando em causa amplos segmentos da sociedade civil no acesso aos bens da civilização. Dispondo de uma dimensão estrutural, ela atinge visceralmente a vida dos sujeitos numa 'luta aberta e surda pela cidadania' (Ianni, 1992), no embate pelo respeito aos direitos civis, sociais e políticos e aos direitos humanos. Esse processo é denso de conformismos e rebeldias, expressando a consciência e a luta pelo reconhecimento dos direitos de cada um e de todos os indivíduos sociais. É nesse terreno de disputas que trabalham os assistentes sociais (IAMAMOTO, 2007, p. 160).

Apreender no movimento do real como tais manifestações transitam da totalidade à particularidade, torna-se um desafio coletivo, que não se inicia nesta quadra histórica. Este documento se apresenta como um esforço para avançarmos no debate da questão étnicoracial na formação profissional, e assim, compreender como as diferentes manifestações e expressões do racismo perpassam os espaços da formação e do exercício profissional, sendo premente a sua apreensão, bem como estratégias para o seu enfrentamento nos diferentes campos de atuação profissional, tendo em vista que o seu "[...] efetivo exercício agrega um complexo de novas determinações e mediações essenciais para elucidar o significado social do trabalho do assistente social" (IAMAMOTO, 2007).

Nesta direção destacam-se as ações desencadeadas pelas Entidades organizativas da categoria (CFESS/CRESS, ENESSO e ABEPSS), a exemplo: a criação e o desenvolvimento do GTP Serviço Social, Relações de Exploração/Opressão de Gênero, Raça/Etnia e Sexualidades da ABEPSS; a campanha do CFESS O Serviço Social: Mudando o rumo da história, de 2003; $039^{\circ}$ Encontro Nacional do Conjunto CFESS/CRESS que aprovou a defesa das políticas afirmativas e cotas raciais por parte do Serviço Social; a brochura do CFESS publicada em 2016: Assistente Social no combate ao preconceito - Caderno 3 'Racismo'; a elaboração e mobilização em torno do documento As cotas na pós-graduação: orientações da ABEPSS para o avanço do debate (2017); o lançamento da mais recente campanha de gestão do conjunto (2018-2021): Assistentes Sociais no combate ao racismo lançada pelo CFESS em 2018; as edições do CFESS Manifesta, em alusão ao 20 de novembro; dentre outras iniciativas promovidas por UFAs e Conselhos Regionais; defesas de teses e dissertações; e, as produções em periódicos como as revistas Libertas (2013), Temporalis (2014), Argumentum (2017), Ser Social (2017) e Serviço Social e Sociedade (2018). 
Tais iniciativas estão no bojo do fortalecimento deste debate. Daí, reforçamos a importância da direção social das Entidades da categoria e suas bases (institucionais e profissionais), que vêm reafirmando os princípios do Código de Ética de 1993, que se reatualiza nesses 25 anos de vigência, com as premissas fundantes:

VI. Empenho na eliminação de todas as formas de preconceito, incentivando o respeito à diversidade, à participação de grupos socialmente discriminados e à discussão das diferenças;

VIII. Opção por um projeto profissional vinculado ao processo de construção de uma nova ordem societária, sem dominação, exploração de classe, etnia e gênero; XI. Exercício do Serviço Social sem ser discriminado/a, nem discriminar, por questões de inserção de classe social, gênero, etnia, religião, nacionalidade, orientação sexual, identidade de gênero, idade e condição física.

Ainda na direção do fortalecimento do projeto ético-político do serviço social, foram estabelecidas as Diretrizes Curriculares de 1996 da ABEPSS ${ }^{2}$ após um amplo e democrático processo de discussão e adensamento coletivo que contou com aproximadamente 200 oficinas locais, regionais e 2 eventos em âmbito nacional entre 1994 e 1996. Elas preconizam, em seus princípios, que a formação profissional implica na capacitação teórico-metodológica, ético-política e técnico-operativa para a:

1. Apreensão crítica do processo histórico como totalidade; 2. Investigação sobre a formação histórica e os processos sociais contemporâneos que conformam a sociedade brasileira, no sentido de apreender as particularidades da constituição e desenvolvimento do capitalismo e do Serviço Social no país; 3. Apreensão do significado social da profissão desvelando as possibilidades de ação contidas na realidade; 4 . Apreensão das demandas - consolidadas e emergentes - postas ao Serviço Social via mercado de trabalho, visando formular respostas profissionais que potenciem o enfrentamento da questão social, considerando as novas articulações entre público e privado; 5. Exercício profissional cumprindo as competências e atribuições previstas na Legislação Profissional em vigor (ASSOCIAÇÃO BRASILEIRA DE ENSINO E PESQUISA EM SERVIÇO SOCIAL, 1996, p. 07).

Com vistas à superação da fragmentação até então presente nos currículos de Serviço Social, a nova organização curricular se baseou em um tripé de conhecimentos constituídos pelos núcleos de fundamentação da formação profissional. São eles:

- Núcleo de fundamentos teórico-metodológicos da vida social, que compreende
um conjunto de fundamentos teórico-metodológicos e ético-políticos para
conhecer o ser social enquanto totalidade histórica, fornecendo os componentes
fundamentais para a compreensão da sociedade burguesa, em seu movimento
contraditório;
- Núcleo de fundamentos da formação sócio-histórica da sociedade brasileira que
remete à compreensão dessa sociedade, resguardando as características
históricas particulares que presidem a sua formação e desenvolvimento urbano e
rural, em suas diversidades regionais e locais. Compreende ainda a análise do
significado do Serviço Social em seu caráter contraditório, no bojo das relações
entre as classes e destas com o Estado, abrangendo as dinâmicas institucionais
nas esferas estatal e privada;
- Núcleo de fundamentos do trabalho profissional que compreende todos os
elementos constitutivos do Serviço Social como uma especialização do trabalho:

${ }^{2}$ Então ABESS, até a mudança ocorrida na convenção de 1997. 
sussions sara o o

sua trajetória histórica, teórica, metodológica e técnica, os componentes éticos que envolvem o exercício profissional, a pesquisa, o planejamento e a administração em Serviço Social e o estágio supervisionado. Tais elementos encontram-se articulados por meio da análise dos fundamentos do Serviço Social e dos processos de trabalho em que se insere, desdobrando-se em conteúdos necessários para capacitar os profissionais ao exercício de suas funções, resguardando as suas competências específicas normatizadas por lei (ASSOCIAÇÃO BRASILEIRA DE ENSINO E PESQUISA EM SERVIÇO SOCIAL, 1999).

Na lógica curricular proposta, os núcleos constituem um conjunto de conhecimentos indissociáveis, não estabelecendo ordem de importância entre eles. "São níveis diferenciados de apreensão da realidade social e profissional, subsidiando a intervenção profissional" (ASSOCIAÇÃO BRASILEIRA DE ENSINO E PESQUISA EM SERVIÇO SOCIAL, 1997). Ao longo da sua implementação, busca-se superar a visão formalista daquele currículo constituído por matérias e disciplinas, descolado de uma perspectiva de totalidade histórica. Assim, "[...] a formação profissional constitui-se de uma totalidade de conhecimentos que estão expressos nestes três núcleos, contextualizados historicamente e manifestos em suas particularidades" (ASSOCIAÇÃO BRASILEIRA DE ENSINO E PESQUISA EM SERVIÇO SOCIAL, 1997).

Considerando que a questão étnico-racial se constitui como um elemento estruturante das relações sociais e, assim, deve ser apreendida com profundidade e em toda a sua complexidade histórica, é subjacente a necessidade de materializar nos currículos e nas propostas pedagógicas (PPCs) um conjunto de disciplinas e atividades de ensino, pesquisa e extensão que promovam na graduação e pós-graduação uma gradativa e efetiva superação da secundarização ou "tematização" da questão étnico-racial na formação, muitas vezes apreendida no viés culturalista e/ou como um segmento a ser abordado no conjunto da sociedade. Vários estudos apontam para os riscos desta fragmentação e silenciamento/ secundarização do debate na formação no Serviço Social no âmbito da graduação e da pós-graduação e, nesse sentido, podemos citar Rocha (2014), Almeida (2016), Dias Almeida (2015), dentre outras.

Cabe destacar que em cada um dos Núcleos de Fundamentação precisam comparecer conteúdos que sustentem uma formação antirracista. Ela deve ser parte de um perfil intelectual e profissional capaz de se desenvolver com os rigores teórico-metodológico, ético-político e técnico-operativo que desafiam a profissão no seu exercício cotidiano, decifrando as mediações para a compreensão do real e sustentando o trabalho profissional que tem junto à população negra possibilidades de desenvolvimento de estratégias para o fortalecimento de processos de acesso aos direitos, da auto-organização da classe e da superação do racismo institucional (EURICO, 2017).

Nesta mesma direção, a inclusão nos conteúdos de disciplinas e em atividades curriculares dos temas sobre Educação das Relações Étnico-Raciais e dos conhecimentos de matriz africana e/ou que dizem respeito à população negra é premente no processo de formação em Serviço Social. Para além de cumprir ditames legais, o compromisso ético-político profissional com a construção de uma sociedade mais justa e igualitária deve assegurar que essa discussão não fique à margem dos debates macrossociais, como os que tratam da contrarreforma do Estado, que tem impacto avassalador sobre as camadas mais empobrecidas da sociedade; da reestruturação produtiva, que joga para a informalidade 
números exorbitantes de trabalhadores; da criminalização da pobreza; e do extermínio da juventude. Estas, entre tantas outras expressões da questão social, têm na população negra o seu peso maior (ROCHA, 2017).

A atualidade das Diretrizes Curriculares se reconfigura nesta conjuntura, uma vez que o projeto de formação profissional - a despeito dos enormes desafios diante do avassalador processo de mercantilização do ensino superior ${ }^{3}$ e dos desafios apresentados à direção social e ao acúmulo do perfil crítico no Serviço Social - tem sido fundamental para o enfrentamento do conservadorismo e dos fortes retrocessos no campo dos direitos sociais com os vorazes ataques à classe trabalhadora nos últimos anos.

Em 2009, "das cerca de 11 milhões de famílias beneficiárias do Programa Bolsa Família [...], em todo o país, cerca de 7,3 milhões de famílias tinham por titular pessoas de cor ou raça [preta] [...] e parda" (PAIXÃO, et al., 2010, p. 133). Pesquisa do IBGE (2011, p. 53) aponta que nas taxas de analfabetismo das pessoas de 15 anos ou mais de idade, "tanto pretos (14,4\%) quanto pardos (13,0\%) mostram um percentual de analfabetismo quase três vezes maior do que o dos brancos (5,9\%)". Assim, pobreza e não acesso a educação expressam implicações sociais que atingem diretamente a classe trabalhadora negra desse país.

Os dados do censo do IBGE (2011) contabilizaram em 2010 uma população brasileira superior a 190 milhões de habitantes. As informações relativas aos números de brasileiros(as) por curso mais elevado concluído na área da educação revelam a desigualdade racial enquanto uma marca das relações raciais no Brasil. No nível mais elementar do ensino fundamental e faixa etária adequada há certo equilíbrio com $51 \%$ de negros(as), $47,6 \%$ de brancos(as) e $1,4 \%$ de amarelos(as)/indígenas. "Segundo o censo, em 2000 apenas 1,7\% da população brasileira frequentava o ensino superior ( $0,7 \%$ da população negra e $2,5 \%$ da população branca). Em 2010, embora a frequência bruta tenha aumentado (3,3\% da população), a desigualdade persiste ( $2,3 \%$ negros $-4,3 \%$ brancos)", (SILVA, 2013, p.20).

Quanto maior o nível de escolaridade, mais visível é a desigualdade. Em relação aos cursos de mestrado e doutorado há que se destacar que $80,7 \%$ dos estudantes neste nível são brancos, $17,1 \%$ negros e 2,2\% correspondem aos grupos populacionais amarelos e indígenas (SILVA, 2013). (ASSOCIAÇÃO BRASILEIRA DE ENSINO E PESQUISA EM SERVIÇO SOCIAL, 2017, p. 2).

\footnotetext{
3 Ler sobre em:

ASSOCIAÇÃO BRASILEIRA DE ENSINO E PESQUISA EM SERVIÇO SOCIAL. Nestes tempos sombrios, a luta por um projeto de formação profissional crítico é ainda mais fundamental. Nota da ABEPSS para o 15 de maio de 2017. Disponível em <http://www.abepss.org.br/noticias/15demaionestestempossombriosalutaporumprojetodeformacaoprofissionalcriticoeaindamaisfundamental-72>. Acesso em: 10 nov. 2018.

ASSOCIAÇÃO BRASILEIRA DE ENSINO E PESQUISA EM SERVIÇO SOCIAL. As cotas na pós-graduação: orientações da ABEPSS para o avanço do debate. Vitória: Brasília, 2017. Disponível em: <http://www.abepss.org.br/noticias/ascotasnaposgraduacaoorientacoesdaabepssparaoavancododebate97>. Acesso em 17 nov. 2018.

LIMA, Kátia. Contrarreforma da educação superior e formação profissional em Serviço Social. Temporalis, Brasília (DF): Associação Brasileira de Ensino e Pesquisa em Serviço Social, n. 15, 2008.

PEREIRA, Larissa Dahmer. Mercantilização do ensino superior, educação à distância e Serviço Social. Revista Katálysis, Florianópolis, v.12, n.2, p. 268-277, jul./dez. 2009.

SANTOS, C. M; ABREU, M.H.E. Os Impactos da Política Nacional de Estágio na Formação Profissional Frente à Universidade Neoliberal. Revista em Pauta, Rio de Janeiro: UERJ, n. 27, 2011.
} 


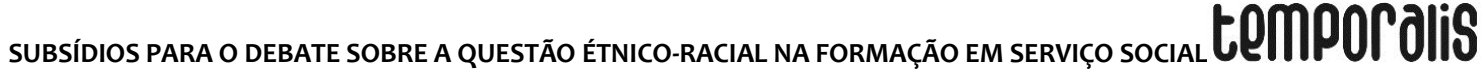

Ademais, nesta conjuntura de crescimento do pensamento com traços do fascismo e ampliação das formas de racismo que têm levado ao extermínio da população negra no Brasil, vale reafirmar a importância de uma educação que respeite o livre pensamento, autônomo e democrático, opondo-se a toda forma de cerceamento do conhecimento, como propõe o projeto Escola sem Partido. Nesta direção, reafirmar e ampliar o compromisso com a implementação da lei Federal $n^{\circ} 10.639 / 2003$, que determina a inclusão no currículo oficial da rede de ensino a obrigatoriedade da temática História da África e Cultura Afro- Brasileira, tem se constituído como um importante instrumento de disputas na formação, pois deve assegurar a inclusão da História da África e da Cultura Afrobrasileira no currículo escolar. Trata de uma pauta essencial e uma reivindicação histórica do movimento negro na luta por uma educação antirracista. Segundo Rocha (2014)

\begin{abstract}
$\mathrm{Na}$ perspectiva de construir um novo modelo educacional, que contemple a história e a riqueza da diversidade humana no processo de formação da sociedade brasileira, a Lei $n^{\circ} 10.639 / 2003$ se constitui em importante instrumento político nesse processo. Sua regulamentação, no ano de 2004, ocorreu a partir da promulgação pelo Conselho Nacional de Educação, através do seu Conselho Pleno, da Resolução n 1, de 17 de junho de 2004, 81 que instituiu as Diretrizes Curriculares Nacionais para a Educação das Relações Étnico-Raciais e para o Ensino de História e Cultura Afro-Brasileira e Africana. $O$ artigo $1^{\circ}$ dessa Resolução preconiza que essas diretrizes devem ser implementadas pelas instituições de ensino, que atuam nos níveis e modalidades da Educação Brasileira e, em especial, por instituições que desenvolvem programas de formação inicial e continuada de professores. (ROCHA, 2014, p. 100).
\end{abstract}

\title{
3 LEVANTAMENTO DE CONTRIBUIÇÕES E REALIZAÇÃO DE EVENTOS/OFICINAS
}

Este documento base apresentado no XVI ENPESS será posteriormente debatido, aprofundado e acrescido de contribuições advindas de ciclos de debates e oficinas organizadas pelas UFAs em articulação com as regionais da ABEPSS, que terão a tarefa de sistematizar as contribuições durante o primeiro semestre de 2019.

Uma vez enviados os relatórios regionais com tais contribuições, o documento será reorganizado/apurado pelo GT nacional (composição indicada pela direção da ABEPSS, com a participação de membros do GTP Serviço social, relações de exploração/opressão de gênero, raça/etnia e sexualidades) e apreciado pela direção para apresentação e aprovação do documento final durante a Oficina Nacional da ABEPSS de 2019.

Sugere-se que os regionais mobilizem as UFAs para o preenchimento das informações a seguir, que poderão ser enviadas por meio eletrônico ou, ainda, por meio de informações/ sugestões coletadas em eventos, oficinas e debates que estimulem a participação e a contribuição de pesquisadores, professores, profissionais e estudantes de graduação e pós-graduação.

Espera-se que tais momentos se constituam como espaços de formação e adensamento em torno do debate da questão étnico-racial, a exemplo, as iniciativas que articulam ABEPSS e Conjunto CFESS/CRESS, tendo em vista o fortalecimento da Campanha Assistentes Sociais no Combate ao Racismo. 


\subsection{Ensino (considerar de 2016 em diante)}

- Disciplinas que comparecem no conteúdo étnico-racial (especificar se a natureza é obrigatória e/ou eletiva, periodicidade da oferta, ementa, $\mathrm{CH}$, período, bibliografia);

- Disciplinas específicas - que tratam prioritariamente do conteúdo. (especificar se a natureza é obrigatória e/ou eletiva, periodicidade da oferta, ementa, $\mathrm{CH}$, período, bibliografia);

- Oficinas, laboratórios (especificar se a natureza é obrigatória e/ou eletiva, periodicidade da oferta, ementa, $\mathrm{CH}$, período, bibliografia);

- Como o tema é tratado na articulação com o Estágio Supervisionado.

\subsection{Extensão (considerar de 2016 em diante)}

- Iniciativas e sugestões de atividades promovidas por meio de atividades na área da extensão universitária;

- Natureza das atividades, conteúdo, objetivos, público, metodologia, $\mathrm{CH}$, periodicidade, bibliografia.

\subsection{Pesquisa e produção do conhecimento (considerar de 2016 em diante)}

- Iniciativas e sugestões de atividades promovidas por meio de atividades na área da pesquisa e da produção de conhecimento;

- Núcleos de estudos e pesquisas

- Pesquisas registradas (concluídas e em andamento);

- TCC, dissertações e teses (título, UFA/Programa, autor, ano, palavras-chave);

- Periódicos/temática/data/forma de acesso.

\subsection{Outras contribuições (considerar de 2016 em diante)}

- Atividades complementares;

- Ações afirmativas (graduação e pós);

- Eventos regionais com a articulação com o conjunto CFESS/CRESS;

- Eventos locais, regionais e nacionais promovidos por UFAS;

- Articulação com movimentos sociais;

- Documentos de orientação e notas

\section{REFERENCIAS}

COUTINHO, C. N. O estruturalismo e a miséria da razão. 2. ed. São Paulo: Expressão Popular, 2010.

ALMEIDA, S. D. Serviço Social e relações raciais: caminhos para uma sociedade sem classes. Temporalis, Brasília (DF), v.15, n. 29, p. 331-333, 2015.

ALMEIDA, Silvio. O que é racismo estrutural? Belo Horizonte: Letramento, 2018. IAMAMOTO, Marilda. Serviço Social em tempos de capital fetiche. São Paulo: Cortez, 2007.

CASHMORE, Ellis. Dicionário de Relações Étnicas e Raciais. São Paulo: Summus, 2000. 
CFESS. Assistente Social no combate ao preconceito: Racismo. Caderno 3. Brasília: CFESS, 2016.

EURICO, M.C. Da Escravidão ao Trabalho Livre: contribuições para o trabalho do assistente social. Ser Social, Brasília (DF), v.19, n. 41, p. 41-42, 2017.

HASENBALG, Carlos. Discriminação e desigualdades raciais no Brasil. Rio de Janeiro: Edições Graal, 1979.

IANNI, Octavio. Raças e classes sociais no Brasil. 3. ed. São Paulo: Brasiliense, 2004.

JANOARIO, R. S.; ROCHA, R. F.; DIAS, Entrevista com Magali da Silva Almeida. Libertas, Juiz de Fora, v. 13, n.1, p. 231-239, 2013.

MUNANGA, Kabengele. Uma abordagem conceitual das noções de raça, racismo, identidade e etnia. 2003. In: SEMINÁRIO NACIONAL RELAÇÕES RACIAIS E EDUCAÇÃO, 3, PENESB-RJ, Rio de Janeiro, Anais..., Rio de Janeiro, 05 nov. 2003. Disponível em: <https://www. ufmg.br/inclusaosocial/?p=59>.

ROCHA, R. da F. A Questão étnico-racial no processo de formação em serviço social. Serviço Social e Sociedade, São Paulo: Cortez, n. 99, p. 54-56, jul./set. 2009.

ROCHA, R. da F. A incorporação da temática étnico-racial no processo de formação em serviço social: avanços e desafios. 2014. Tese (Doutorado em Serviço Social), Escola de Serviço Social, UFRJ, Rio de Janeiro.

SEYFERTH, Giralda. O beneplácito da desigualdade: breve digressão sobre racismo. In: RACISMO no Brasil. São Paulo: Peirópolis; ABONG, 2002.

Gestão da ABEPSS 2017-2018

"Quem é de luta resiste"

Vitória, dezembro de 2018. 